\title{
Penerapan Model Learning Cycle ( LC) 7E Sebagai Upaya Peningkatan Hasil Belajar SisWa Tentang Zat Dan Wujudnya DI KELAS VII
}

\author{
Ade Nurhajjah $^{1)}$, Andika Kusuma Wijaya ${ }^{2)}$, Intan Kusumawati ${ }^{3)}$ \\ 1) Prodi Pendidikan Fisika STKIP Singkawang \\ E-mail: adenurhajjah@yahoo.co.id \\ 2) Prodi Pendidikan Fisika STKIP Singkawang \\ E-mail: andikakusumawijaya1988@gmail.com \\ 3) Prodi Pendidikan Fisika STKIP Singkawang \\ E-mail: intankusumawati10@gmail.com
}

\begin{abstract}
Abstrak. Penelitian ini bertujan untuk mendapatkan gambaran mengenai skor rata-rata hasil belajar siswa, mengetahui peningkatan hasil belajar siswa dan respon siswa terhadap penerapan model LC 7E pada hasil belajar siswa tentang zat dan wujudnya. Bentuk desain penelitian yang digunakan pre experimental design dengan one group pre-test post-test design. Populasi pada penelitian ini adalah seluruh siswa kelas VII di SMP Torsina Singkawang. Teknik pengambilan sampel menggunakan sampling purposive yang berjumlah 16 orang. Hasil penelitian menunjukkan bahwa model LC 7E dapat meningkatkan hasil belajar siswa dengan skor $N$-gain sebesar 0,55 dengan kategori sedang. Respon siswa terhadap model LC 7E sebesar 80\% dengan kategori positif.
\end{abstract}

Kata Kunci: Learning Cycle 7E; Hasil Belajar

\section{Pendahuluan}

Fisika adalah ilmu pengetahuan yang paling mendasar karena berhubungan dengan perilaku dan struktur benda [1] [2]. Tujuan pembelajaran fisika diharapkan dapat mengembangkan sikap rasa ingin tahu, memahami konsep fisika dan mampu mengaplikasikannya dalam kehidupan sehari-hari untuk memecahkan masalah dan sebagai dasar untuk melanjutkan ke jenjang berikutnya [3] [4].

Berdasarkan hasil wawancara dengan guru bidang studi IPA bahwa hasil belajar ranah kognitif siswa di kelas VII SMP Torsina masih tergolong rendah, hal ini dibuktikan dengan hasil ranah kognitif diperoleh rata-rata nilai 53 dari nilai maksimal pada materi zat dan wujudnya sehingga siswa tidak dapat mencapai Kriteria Ketuntasan Minimal (KKM). Hal ini dikarenakan guru bidang studi fisika cenderung menggunakan metode konvensional [5] [6]. Pendekatan konvensional ditandai dengan guru mengajar lebih banyak mengajarkan tentang konsep-konsep bukan kompetensi, tujuannya adalah siswa mengetahui sesuatu bukan mampu untuk melakukan sesuatu, dan saat proses pembelajaran siswa lebih banyak mendengarkan [7] [8].
Satu di antara materi pembelajaran fisika yang wajib dipelajari siswa SMP adalah materi zat dan wujudnya yang memiliki aplikasi dalam kehidupan sehari-hari. Dalam mengikuti pembelajaran, siswa cenderung lebih senang mengikuti perintah guru [9]. Oleh karena itu, saat ini diperlukan model pembelajaran fisika yang dapat meningkatkan hasil belajar siswa [10].

Satu di antara model pembelajaran yang dimaksud adalah model Learning Cycle 7E. Model Learning Cycle 7E merupakan suatu model pembelajaran yang berpusat pada peserta didik. Melalui model Learning Cycle 7E diharapkan dapat meningkatkan hasil belajar siswa terutama tentang materi zat dan wujudnya di kelas VII SMP Torsina Singkawang.

\section{METODE}

Berdasarkan tujuan yang ingin dicapai yaitu untuk mengetahui keterampilan berpikir kritis siswa dengan menggunakan model pembelajaran LC 7E, maka dalam penelitian ini menggunakan jenis penelitian kuantitatif, metode yang digunakan pada jenis penelitian ini adalah PreExperimental Design. Desain penelitian ini adalah One Group 


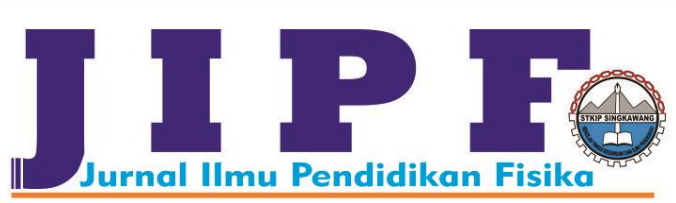

Pre test-Post test Design. Sampel penelitian diberi perlakuan (treatment) selama waktu tertentu. Populasi dalam penelitian ini adalah seluruh siswa kelas VII SMP Torsina Singkawang. Teknik pengambilan sampel dalam penelitian ini adalah purposive sampling, peneliti menentukan sendiri sampel yang diambil karena ada pertimbangan tertentu. Dalam penelitian ini yang menjadi sampel penelitian adalah siswa kelas VII SMP Torsina Singkawang yang terdiri dari 16 siswa.

Penelitian ini terdiri dari variabel bebas dan terikat. Variabel bebas dalam penelitian ini adalah model LC 7E, sedangkan variabel terikat adalah hasil belajar dan respon siswa. Teknik pengumpulan data pada penelitian ini mengguanakan tes dan observasi.

Tes yang diberikan berupa soal pre-test sebelum treatment dan post-test setelah treatment yang diberikan untuk melihat peningkatan hasil belajar siswa. Adapun instrument pengumpul data yang digunakan antara lain (1) lembar observasi aktivitas belajar siswa, (2) lembar respon siswa, (3) lembar pre-test dan post-test. Sebelum tes digunakan dalam penelitian, terlebih dahulu dilakukan uji coba. Data hasil uji coba instrumen kemudian diolah atau dianalisis.

\section{HASIL DAN PEMBAHASAN}

Untuk menggambarkan peningkatan hasil belajar siswa pada materi zat dan wujudnya, kategori peningkatan hasil belajar diadaptasi dari kategori $\mathrm{N}$-gain sebagai berikut.

TABEL 1

KRITERIA FAKTOR N-GAIN $\langle\mathrm{G}\rangle$

\begin{tabular}{cc}
\hline Skor N-gain & Kategori \\
\hline$<\mathrm{g}>\geq 0,7$ & Tinggi \\
$0,3 \leq<\mathrm{g}><0,7$ & Sedang \\
$<\mathrm{g}><0,3$ & Rendah
\end{tabular}

Peningkatan hasil belajar siswa diperoleh dari hasil ratarata pre test dan rata-rata post test yang dinormalisasii dengan uji gain ternormaisasi. Adapun hasil perhitungan N-gain menggunakan persamaan sebagai berikut.

$$
\begin{aligned}
<g> & =\frac{s_{\text {post test }}-S_{\text {pre test }}}{s_{\text {maksimum }}-S_{\text {pre test }}} \\
& =\frac{75-43,68}{100-43,68}=\frac{31,32}{56,32}=0,55
\end{aligned}
$$

Berdasarkan perhitungan tersebut diungkapkan bahwa skor rata-rata hasil belajar siswa setelah dinormalisasikan dengan uji $\mathrm{N}$-gain diperoleh peningkatan nilai sebesar 0,55 , maka hasil belajar siswa diperoleh peningkatan dengan kriteria sedang karena 0,55 berada pada rentang $0,3 \leq<g><0,7$. Peningkatan hasil belajar ranah kognitif siswa merupakan perubahan yang ditimbulkan sebelum dan sesudah proses pembelajaran berlangsung. Apabila dikaji dari standar Kriteria Ketuntasan Minimal (KKM) pelajaran fisika sebesar 65,00 maka nilai rata-rata post test hasil belajar siswa sudah mencapai standar KKM. Nilai rata-rata hasil belajar siswa pada post test sebesar 66,87 . Hal ini membuktikan bahwa model pembelajaran learning cycle 7E dapat meningkatkan hasil belajar siswa pada materi zat dan wujudnya di kelas VII SMP Torsina Singkawang.

\section{KESIMPULAN}

Berdasarkan hasil dan pembahasan yang dilakukan dapat disimpulkan bahwa terdapat peningkatan hasil belajar siswa sebesar 0,55 dengan kriteria sedang. Model learning cycle 7E dapat meningkatkan hasil belajar siswa dan tidak hanya mengukur ranah kognitif saja tetapi juga dapat mengukur ranah efektif dan psikomotor siswa.

\section{DAFTAR PUSTAKA}

[1] Giancolli, D.C. (2001). Fisika Edisi Kelima. Jakarta: Erlangga.

[2] Permendiknas No 22 tahun 2006. (2006). Tentang Standar Isi Pendidikan Dasarn dan Menengah. Jakarta

[3] Irhamna, Rosdianto, H., \& Murdani, E. (2017). Penerapan Model Learning Cycle 5E untuk Meningkatkan Keterampilan Berpikir Kritis Siswa Pada Materi Fluida Statis Kelas VIII. Jurnal Fisika Flux, 14(1): 61-64.

[4] Rosdianto, H. (2017). Students` Conceptual Understanding through Generative Learning Model in Topic "Light". JPI (Jurnal Pendidikan Indonesia), 6(2): 259-262

[5] Sulistri, E., \& Lisdawati, L. (2017). Using Three-Tier Test to Identify the Quantity of Student that Having Misconception on Newton's Laws of Motion Concept. JIPF (Jurnal Ilmu Pendidikan Fisika), 2(1): 4-6.

[6] Siradjuddin, Rosdianto, H., \& Sulistri, E. (2018). Penerapan Model REACT Untuk Meningkatkan Keterampilan Proses Sains Siswa Pada Materi Arus Listrik. Jurnal Pendidikan Fisika dan Keilmuan (JPFK), 4(1): $17-22$

[7] Sukandi. (2003). Metodelogi Penelitian Pendidikan. Jakarta: Bumi Aksara.

[8] Nadiya, Rosdianto, H., \& Murdani, E. (2016). Penerapan Model Pembelajaran Group Investigation (GI) untuk Meningkatkan Keterampilan Berpikir Kritis Siswa pada Materi Gerak Lurus Kelas X. JIPF (Jurnal Ilmu Pendidikan Fisika), 1(2): 49-51

[9] Rosdianto, H., Murdani, E., \& Hendra. (2017). The Implementation of POE (Predict Observe Explain) Model to Improve Student's Concept Understanding on Newton's Law. Jurnal Pendidikan Fisika, 6(1): 55-57. https://doi.org/10.22611/jpf.v6i1.6899

[10] Rosdianto, H. (2017). Pengaruh Model Generative Learning Terhadap Hasil Belajar Ranah Kognitif Siswa Pada Materi Hukum Newton. Jurnal Pendidikan Fisika dan Keilmuan (JPFK), 3(2): 66-69. 